\title{
Antibacterial scalarane from Doriprismatica stellata nudibranchs (Gastropoda, Nudibranchia), egg ribbons, and their dietary sponge Spongia cf. agaricina (Demospongiae, Dictyoceratida)
}

\author{
Cora Hertzer $^{1}$, Stefan Kehraus ${ }^{1}$, Nils Böhringer ${ }^{2,3}$, Fontje Kaligis ${ }^{4, \S}$, Robert Bara ${ }^{4}$, \\ Dirk Erpenbeck ${ }^{5,6}$, Gert Wörheide ${ }^{5,6,7}$, Till F. Schäberle ${ }^{2,3}$, Heike Wägele ${ }^{8}$ \\ and Gabriele M. König ${ }^{*}$, ๆ
}

\section{Full Research Paper}

\author{
Address: \\ ${ }^{1}$ Institute for Pharmaceutical Biology, University of Bonn, Nussallee 6, \\ 53115 Bonn, Germany, ${ }^{2}$ Institute for Insect Biotechnology, \\ Justus-Liebig-University, Heinrich-Buff-Ring 26-32, 35392 Gießen, \\ Germany, ${ }^{3}$ Department for Bioresources of the Fraunhofer Institute \\ for Molecular Biology and Applied Ecology, Ohlebergsweg 12, 35392 \\ Gießen, Germany, ${ }^{4}$ Faculty of Fisheries and Marine Science, Sam \\ Ratulangi University, Jl. Kampus UNSRAT Bahu, 95115 Manado, \\ Sulawesi Utara, Indonesia, ${ }^{5}$ Department of Earth and Environmental \\ Sciences, Palaeontology \& Geobiology, \\ Ludwig-Maximilians-Universität München, Richard-Wagner-Str. 10, \\ 80333 München, Germany, ${ }^{6}$ GeoBio-Center, \\ Ludwig-Maximilians-Universität München, Richard-Wagner-Str. 10 , \\ 80333 München, Germany, ${ }^{7}$ SNSB - Bayerische Staatssammlung für \\ Paläontologie und Geologie, Richard-Wagner-Str. 10, 80333 \\ München, Germany and ${ }^{8}$ Zoologisches Forschungsmuseum \\ Alexander Koenig, Adenauerallee 160, 53113 Bonn, Germany \\ Email: \\ Gabriele M. König ${ }^{*}$ - g.koenig@uni-bonn.de \\ * Corresponding author \\ $\S$ deceased \\ ๆ Tel.: +49228733747. Fax: +49228733250 \\ Keywords: \\ antibacterial; Dictyoceratida; Nudibranchia; scalarane; sesterterpene
}

Beilstein J. Org. Chem. 2020, 16, 1596-1605.

doi:10.3762/bjoc. 16.132

Received: 23 April 2020

Accepted: 23 June 2020

Published: 03 July 2020

Associate Editor: C. Stephenson

(C) 2020 Hertzer et al.; licensee Beilstein-Institut.

License and terms: see end of document.

\footnotetext{
Abstract

Investigations on the biochemical relationship between Doriprismatica stellata (Chromodorididae, Doridoidea) nudibranchs, their egg ribbons, and the associated dietary sponge Spongia cf. agaricina (Demospongiae, Porifera) led to the isolation of the structurally new scalarane-type sesterterpene 12-deacetoxy-4-demethyl-11,24-diacetoxy-3,4-methylenedeoxoscalarin, with an unprecedented position of the cyclopropane ring annelated to the ring A. Unlike other scalaranes, which are most often functionalized at
} 
C-12 of ring C, it bears two acetoxy groups at C-11 and C-24 instead. The compound was present in all three samples, supporting the dietary relationship between chromodorid nudibranchs of the genus Doriprismatica and scalarane-containing dictyoceratid sponges of the Spongiidae family. The results also indicate that D. stellata passes the scalarane metabolite on to its egg ribbons, most likely for protective purposes. The scalarane showed antibacterial activity against the Gram-positive bacteria Arthrobacter crystallopoietes (DSM 20117) and Bacillus megaterium (DSM 32).

\section{Introduction}

In habitats with intense competition and feeding pressure, such as coral reefs, sessile or slow-moving organisms commonly defend themselves with toxic or deterrent molecules [1-8]. Sponges (Porifera), for example, represent one of the main sources of marine bioactive natural products, due to their impressive chemical armoury [4]. These specialized metabolites can be produced either by the sponge itself or by associated microbial symbionts [9-16]. Their production is assumed to be useful against numerous environmental stress factors, such as predation, pathogens, overgrowth by fouling organisms, or competition for space $[4,10,15,17]$.

Though defensive metabolites are effective against most predators, some also attract nudibranchs of the family Chromodorididae (Gastropoda, Mollusca). These colorful, shell-less sea slugs are specialized to live and feed on noxious demosponges (Demospongiae, Porifera). They evolved the ability to sequester, accumulate, and store spongian metabolites to their own advantage $[2,5,9,18-33]$. Besides, specific metabolites can be passed on from the sea slugs to their similarly conspicuous and physically defenceless eggs. This has been shown exemplarily for the egg ribbons of certain nudipleuran taxa, such as Hexabranchus sanguineus [17], Pleurobranchaea maculata [34], Cadlina luteomarginata [35], and the two Dendrodoris species D. grandiflora and D. limbata [36]. The passing on of special metabolites from sea slugs to their egg ribbons suggests an additional biological role in the reproductive cycle or as protection of the eggs against predation or fouling.

Chemotaxonomic approaches have shown that chromodorid nudibranchs of the genera Chromodoris, Doriprismatica, Felimare, Felimida, Glossodoris/Casella, and Goniobranchus sequester and reuse spongian-type furanoterpenoids, diterpenoids, and sesquiterpenoids, or scalarane-type sesquiterpenoids and sesterterpenoids from their sponge prey [23,37-45]. However, confusion in the chemotaxonomy of Chromodorididae arose by multiple changes in the species names, including splitting and synonymizations, and the inclusion of species that have since been discovered to be members of other genera Additionally, a splitting of generic groups into several genera and resurrection of old names increased the confusion $[39,42,46-49]$. To classify specialized metabolites in the Chro- modorididae in a meaningful way, a solid understanding of their taxonomy, biology, and prey is essential.

Members of Glossodoris/Casella and Doriprismatica represent such a case of complex systematic challenges and complicated taxonomic histories [49]. Previous work on Doriprismatica (former Glossodoris) sedna [39] and Doriprismatica (former Glossodoris or Casella) atromarginata [38,41,44,45,50], reported the isolation of scalaranes, homoscalaranes, norscalaranes, spongian diterpenoids and furanoditerpenoids. A dietary origin of these molecules was inferred and attributed to dictyoceratid sponges of the genera Hyrtios and Carteriospongia (Thorectidae), as well as Hyattella and Spongia (Spongiidae). A geographical variation was described between D. atromarginata populations from Sri Lanka and Australia, containing furanoditerpenes, and a $D$. atromarginata population from India, containing scalarane sesterterpenes as a consequence of sponge prey availability [41]. The isolated metabolites showed various biological activities, such as cytotoxicity, antimicrobial, antiviral and antitumor activities, inhibition of transactivation for the farnesoid $\mathrm{X}$ receptor, inhibition of mammalian phospholipase $\mathrm{A}_{2}$, and ichthyotoxicity against the mosquitofish Gambusia affinis [28,29,39,51-56]. Furthermore, a Vietnamese collection of D. atromarginata was found on the gorgonian Menella woodin (Plexauridae, Alcyonacea). Instead of spongian- or scalarane-type metabolites, they contained steroidal compounds, presumably sequestered from $M$. woodin [57].

Here, we report the first investigation on the biochemical relationship between Doriprismatica (former Glossodoris) stellata (Chromodorididae, Doridina) of the Indo-West Pacific (Figure 1), their egg ribbons, and the associated dietary sponge, identified as Spongia cf. agaricina (Spongiidae, Demospongiae). We describe the structure elucidation of the new scalarane sesterterpene 12-deacetoxy-4-demethyl-11,24diacetoxy-3,4-methylenedeoxoscalarin (Figure 2), isolated from all our Doriprismatica stellata nudibranch, egg ribbon and Spongia cf. agaricina samples (Figure 3). It is the first scalarane sesterterpene reported with a cyclopropane ring bridging the carbons $\mathrm{C}-3, \mathrm{C}-22$ and $\mathrm{C}-4$ in ring $\mathrm{A}$, and an acetoxy group at C-11 instead of C-12 in ring C (Figure 2). All ethyl acetate 


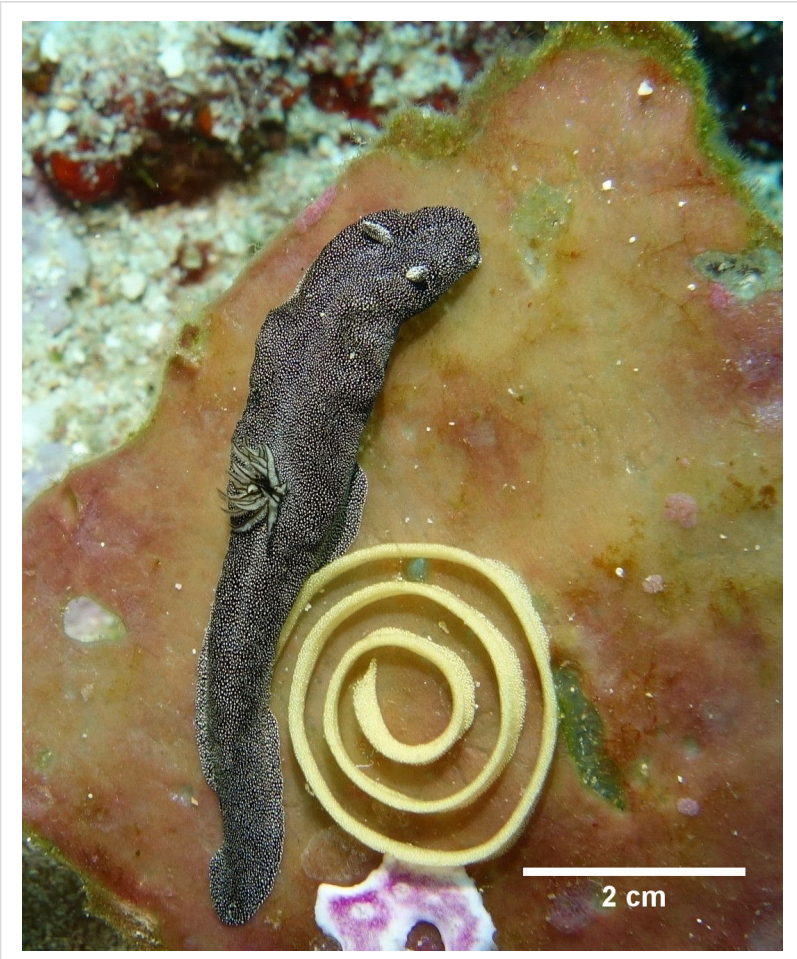

Figure 1: Doriprismatica stellata nudibranch, egg ribbon, and Spongia cf. agaricina specimen.

extracts, as well as the isolated new scalarane, showed antibacterial activity against the Gram-positive bacteria Arthrobacter crystallopoietes (DSM 20117) and Bacillus megaterium (DSM 32 ), in a screening approach.

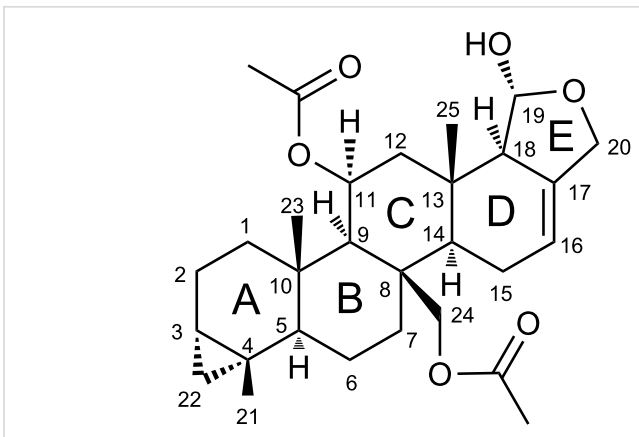

Figure 2: The structurally new 12-deacetoxy-4-demethyl-11,24-diacetoxy-3,4-methylenedeoxoscalarin (relative stereochemistry depicted), isolated from Doriprismatica stellata nudibranchs, their egg ribbons and the dietary sponge Spongia cf. agaricina.

\section{Results}

\section{Chemical investigation on Doriprismatica} stellata nudibranchs, egg ribbons and Spongia cf. agaricina

The new molecule was isolated as a white amorphous solid from D. stellata nudibranchs (11 mg, $0.3 \%$ wet weight). Specific optical rotation was measured in chloroform $(c=0.6)$, giving $[\alpha]_{D}+40.5$. The molecular formula $\mathrm{C}_{29} \mathrm{H}_{42} \mathrm{O}_{6}$ was established based on ${ }^{13} \mathrm{C}$ NMR data and HRAPCIMS measurements, yielding $m / z 487.3054[\mathrm{M}+\mathrm{H}]^{+}$(Supporting Information File 1). The double bond equivalent (DBE) was calculated to be nine and together with the ${ }^{13} \mathrm{C}$ NMR data, giving evidence for one $\mathrm{C}-\mathrm{C}$ and two $\mathrm{C}-\mathrm{O}$ double bonds, thus suggested a structure

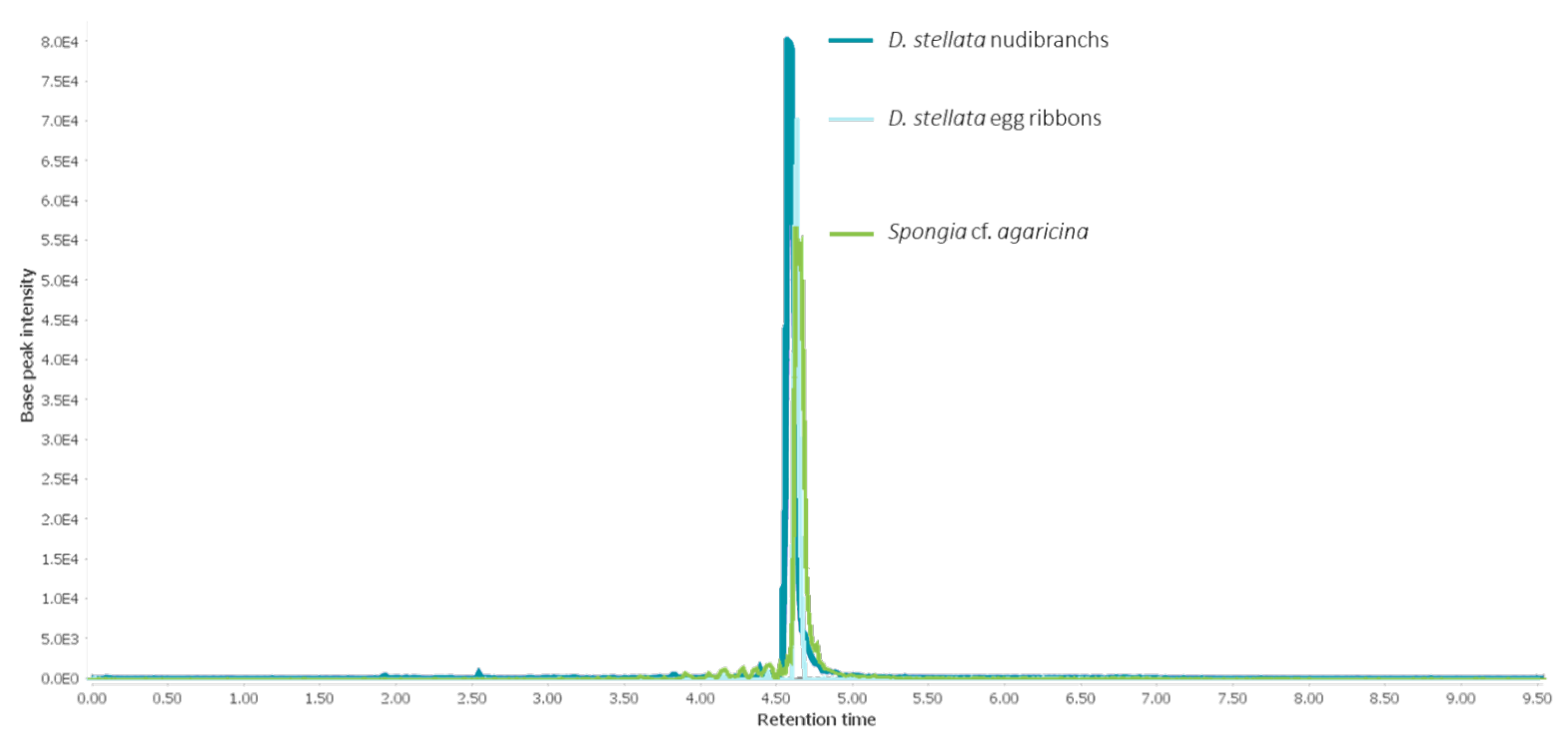

Figure 3: Superimposed HPLC-MS chromatogram of Doriprismatica stellata nudibranch, egg ribbon, and Spongia cf. agaricina extracts, showing the presence of 12-deacetoxy-4-demethyl-11,24-diacetoxy-3,4-methylenedeoxoscalarin in all three samples. 
with six rings. The presence of a hydroxy group and ester functionalities was deduced from characteristic IR absorptions at 3416,1732 and $1234 \mathrm{~cm}^{-1}$ (Supporting Information File 1) $[39,40,53]$.
The planar structure of 12-deacetoxy-4-demethyl-11,24-diacetoxy-3,4-methylenedeoxoscalarin was established by extensive 1D and 2D NMR experiments $\left({ }^{1} \mathrm{H},{ }^{13} \mathrm{C},{ }^{1} \mathrm{H},{ }^{1} \mathrm{H}-\mathrm{COSY}\right.$, DEPT, HSQC and HMBC, see Table 1, Figure S8, Supporting Informa-

\begin{tabular}{|c|c|c|c|c|c|}
\hline C & $\begin{array}{l}\delta_{\mathrm{H}} \\
\text { (mult. } J \text { in Hz) }\end{array}$ & $\delta_{C}$ & COSY & HMBC & NOESY \\
\hline $1 \beta$ & $1.73, \mathrm{~m}$ & $35.3, \mathrm{CH}_{2}$ & $H-1 \alpha, H-2 \alpha / \beta$ & $\begin{array}{l}\text { C-2, C-3, C-5, C-9, C-10, } \\
\text { C-23 }\end{array}$ & $\mathrm{H}-1 \alpha, \mathrm{H}-11$ \\
\hline $1 \alpha$ & $0.53, \mathrm{~m}$ & & $H-1 \beta, H-2 \alpha / \beta$ & $\begin{array}{l}\text { C-2, C-3, C-5, C-9, C-10, } \\
\text { C-23 }\end{array}$ & $\mathrm{H}-1 \beta, \mathrm{H}-22 \mathrm{~b}$ \\
\hline $2 \beta$ & $1.96, \mathrm{~m}$ & $19.0, \mathrm{CH}_{2}$ & $H-3, H-1 \alpha / \beta, H-2 \alpha$ & C-1, C-2, C-22 & $\mathrm{H}-2 \alpha, \mathrm{H}-3, \mathrm{H}_{3}-23$ \\
\hline $2 \alpha$ & $1.70, \mathrm{~m}$ & & $\mathrm{H}-3, \mathrm{H}-1 \alpha / \beta, \mathrm{H}-2 \beta$ & $\mathrm{C}-1, \mathrm{C}-2, \mathrm{C}-22$ & $\mathrm{H}-2 \beta$ \\
\hline 3 & $0.55, \mathrm{~m}$ & $17.9, \mathrm{CH}$ & $H-22 \alpha / \beta, H-2 \alpha / \beta$ & $\begin{array}{l}\text { C-1, C-2, C-4, C-5, C-10, } \\
\text { C-21, C-22 }\end{array}$ & $\mathrm{H}_{3}-21, \mathrm{H}_{3}-23, \mathrm{H}-22 \mathrm{a}$ \\
\hline 4 & & $16.1, \mathrm{C}$ & & & \\
\hline 5 & $0.92, \mathrm{~m}$ & $53.2, \mathrm{CH}$ & $\mathrm{H}-6 \mathrm{a} / \mathrm{b}$ & $\begin{array}{l}\text { C-1, C-6, C-7, C-10, C-21, } \\
\text { C-22, C-23 }\end{array}$ & $\mathrm{H}-9, \mathrm{H}-22 \mathrm{~b}$ \\
\hline $6 a$ & $1.68, \mathrm{~m}$ & 22.1, $\mathrm{CH}_{2}$ & $H-5, H-6 b, H-7 \alpha / \beta$ & C-5, C-7, C-8, C-10 & $H-6 b$ \\
\hline $6 b$ & $1.49, \mathrm{~m}$ & & $H-5, H-6 a, H-7 \alpha / \beta$ & C-5, C-7, C-8, C-10 & $\mathrm{H}-6 \mathrm{a}$ \\
\hline $7 \beta$ & 2.42, m & $36.5, \mathrm{CH}_{2}$ & $\mathrm{H}-6 \mathrm{a} / \mathrm{b}, \mathrm{H}-7 \alpha$ & C-6, C-8, C-9, C-14, C-24 & $\mathrm{H}-7 \beta$ \\
\hline $7 \alpha$ & $0.81, \mathrm{~m}$ & & $\mathrm{H}-6 \mathrm{a} / \mathrm{b}, \mathrm{H}-7 \beta$ & C-6, C-8, C-9, C-14, C-24 & $\mathrm{H}-7 \alpha, \mathrm{H}-14$ \\
\hline 8 & & $41.2, \mathrm{C}$ & & & \\
\hline 9 & $1.01, \mathrm{~s}$ & $57.4, \mathrm{CH}$ & $\mathrm{H}-11$ & C-8, C-10, C-23, C-24 & $\mathrm{H}-5, \mathrm{H}-11, \mathrm{H}-14$ \\
\hline 10 & & $36.5, \mathrm{C}$ & & & \\
\hline 11 & 5.49, brs & $68.4, \mathrm{CH}$ & $\mathrm{H}-9, \mathrm{H}-12 \alpha / \beta$ & $\begin{array}{l}\text { C-8, C-9, C-10, C-11-OAc, } \\
\text { C-12, C-13 }\end{array}$ & $H-1 \alpha, H-9, H-12 \alpha / \beta$ \\
\hline $12 \beta$ & $2.19, \mathrm{~m}$ & $44.2, \mathrm{CH}_{2}$ & $\mathrm{H}-11, \mathrm{H}-12 \alpha$ & $C-11, C-13, C-25$ & $H-12 \alpha$ \\
\hline $12 \alpha$ & $1.51, \mathrm{~m}$ & & $\mathrm{H}-11, \mathrm{H}-12 \beta$ & $C-11, C-13, C-25$ & $\mathrm{H}-12 \beta$ \\
\hline 13 & & $32.5, \mathrm{C}$ & & & \\
\hline 14 & 1.40, brt $(8.5)$ & $55.0, \mathrm{CH}$ & $H-15 \alpha / \beta$ & $\begin{array}{l}\text { C-8, C-9, C-13, C-15, C-18, } \\
\text { C-24 }\end{array}$ & $\mathrm{H}-9, \mathrm{H}-18$ \\
\hline $15 a / b$ & 2.27, m & $24.0, \mathrm{CH}_{2}$ & $\mathrm{H}-14, \mathrm{H}-16$ & & $\mathrm{H}-16$ \\
\hline 16 & 5.49, brs & $117.5, \mathrm{CH}$ & $H-20 \alpha / \beta, H-18, H-15 \alpha / \beta$ & & $\mathrm{H}-20 \mathrm{~b}, \mathrm{H}-15 \mathrm{a} / \mathrm{b}$ \\
\hline 17 & & 135.6, C & & & \\
\hline 18 & $2.15, \mathrm{~m}$ & $62.7, \mathrm{CH}$ & $\mathrm{H}-16, \mathrm{H}-19$ & C-13, C-14, C-19, C-25 & $\mathrm{H}-12 \alpha, \mathrm{H}-14$ \\
\hline 19 & $5.24, \mathrm{~d}(4.4)$ & $98.9, \mathrm{CH}$ & $\mathrm{H}-18$ & C-13, C-17, C-18, C-20 & $\mathrm{H}-12 \beta, \mathrm{H}_{3}-25$ \\
\hline $20 a$ & $4.44, d(12.2)$ & $68.8, \mathrm{CH}_{2}$ & $\mathrm{H}-16, \mathrm{H}-20 \mathrm{~b}$ & & $\mathrm{H}-20 \mathrm{~b}$ \\
\hline $20 \mathrm{~b}$ & $4.15, d(12.2)$ & & $\mathrm{H}-16, \mathrm{H}-20 \mathrm{a}$ & C-16, C-17, C-18, C-19 & $\mathrm{H}-16, \mathrm{H}-20 \mathrm{a}$ \\
\hline 21 & $0.94, \mathrm{~s}$ & 23.3, $\mathrm{CH}_{3}$ & & C-3, C-4, C-5, C-22 & $\mathrm{H}-3, \mathrm{H}-22 \mathrm{a}$ \\
\hline $22 a$ & $0.43, \mathrm{dd}(3.9,9.2)$ & 22.7, $\mathrm{CH}_{2}$ & $\mathrm{H}-3, \mathrm{H}-22 \mathrm{~b}$ & $\mathrm{C}-2, \mathrm{C}-5, \mathrm{C}-21$ & $\mathrm{H}-3, \mathrm{H}-22 \mathrm{~b}$ \\
\hline $22 b$ & -0.06, brt $(4.8)$ & & $\mathrm{H}-3, \mathrm{H}-22 \mathrm{a}$ & $C-2, C-5, C-21$ & $H-1 \alpha, H-5, H-22 a$ \\
\hline 23 & $0.95, \mathrm{~s}$ & $14.0, \mathrm{CH}_{3}$ & & C-1, C-5, C-9, C-10 & $\mathrm{H}-3, \mathrm{H}-24 \mathrm{a}$ \\
\hline $24 a$ & $4.91, d(12.9)$ & $64.2, \mathrm{CH}_{2}$ & $H-24 b$ & C-7, C-8, C-9, C-14, 24-OAC & $\mathrm{H}_{3}-23$ \\
\hline $24 b$ & $4.81, \mathrm{~d}(12.9)$ & & $\mathrm{H}-24 \mathrm{a}$ & $\begin{array}{l}\text { C-7, C-8, C-9, C-14, 24, } \\
24-O A c\end{array}$ & $\mathrm{H}_{3}-25$ \\
\hline 25 & $0.98, \mathrm{~s}$ & 16.1, $\mathrm{CH}_{3}$ & & C-12, C-13, C-14, C-18 & $\mathrm{H}-19, \mathrm{H}-24 \mathrm{~b}$ \\
\hline \multirow[t]{2}{*}{ 11-OAc } & $2.06, \mathrm{~s}$ & $21.9, \mathrm{CH}_{3}$ & & $\mathrm{C}-11$ & \\
\hline & & $170.2, \mathrm{C}$ & & & \\
\hline \multirow[t]{2}{*}{ 24-OAc } & $2.08, \mathrm{~s}$ & 21.3, $\mathrm{CH}_{3}$ & & C-24 & \\
\hline & & $170.9, \mathrm{C}$ & & & \\
\hline
\end{tabular}

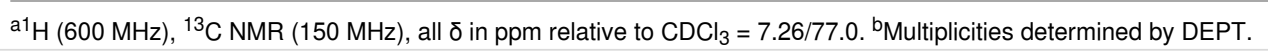


tion File 1). The ${ }^{13} \mathrm{C}$ NMR spectrum showed 29 resonances attributable to five methyl groups, nine methylene and eight methine moieties (one olefin: C-16 ( $\delta 117.5)$, and two oxygen bearing groups: $\mathrm{C}-11(\delta 68.4)$ and $\mathrm{C}-19(\delta 98.9))$, and seven quaternary carbons, as obvious from a DEPT135 spectrum. The ${ }^{1} \mathrm{H}$ NMR spectrum showed unusual upfield resonances, diagnostic for a cyclopropyl ring $\mathrm{H}_{2}-22(\delta-0.06 \mathrm{brt}, J=4.8 \mathrm{~Hz}$, $\delta 0.43 \mathrm{dd}, J=3.9,9.2 \mathrm{~Hz}$ ). Furthermore, this spectrum proved the presence of the olefinic proton $\mathrm{H}-16$ ( $\delta 5.49 \mathrm{brs}$ ), the downfield shifted methine proton $\mathrm{H}-11$ ( $\delta 5.49 \mathrm{brs}$ ), and the hemiacetal hydrogen atom $\mathrm{H}-19(\delta 5.24 \mathrm{~d}, J=4.4 \mathrm{~Hz})$. The ${ }^{1} \mathrm{H}$ NMR spectrum also featured two downfield shifted methylene systems $\mathrm{H}_{2}-20(\delta 4.44, \delta 4.15 \mathrm{~d}, J=12.2 \mathrm{~Hz})$ and $\mathrm{H}_{2}-24$ $(\delta 4.91, \delta 4.81 \mathrm{~d}, J=12.9 \mathrm{~Hz}$ ), as well as two acetoxy groups $\mathrm{H}_{3}-11-\mathrm{OAc}(\delta 2.06 \mathrm{~s})$ and $\mathrm{H}_{3}-24-\mathrm{OAc}(\delta 2.08 \mathrm{~s})$, and three methyl groups $\mathrm{H}_{3}-21$ ( $\left.\delta 0.94 \mathrm{~s}\right), \mathrm{H}_{3}-23(\delta 0.95 \mathrm{~s})$, and $\mathrm{H}_{3}-25$ ( $\delta 0.98 \mathrm{~s})$.

The analysis of the 2D NMR data and comparison to literature values [53] suggested that the compound belongs to the family of scalarane sesterterpenoids, with similarities to the deoxoscalarin-like molecule 12,24-diacetoxydeoxoscalarin, previously isolated from a Korean sponge of the genus Spongia [53]. The two acetoxy groups were located at the C-11 ( $\delta$ 68.4) and the $\mathrm{C}-24(\delta 64.2)$ carbon atoms based on HMBC cross peaks between the methine proton $\mathrm{H}-11$ ( $\delta 5.49$ brs) and the carbon atoms $\mathrm{C}-11-\mathrm{OAc}(\delta 21.9,170.2)$, as well as the methylene protons $\mathrm{H}_{2}-24(\delta 4.91, \delta 4.81 \mathrm{~d}, J=12.9 \mathrm{~Hz})$ and the carbon atoms $\mathrm{C}-24-\mathrm{OAc}(\delta 21.3,170.9)$. The location of $\mathrm{C}-24$ was apparent from HMBC cross peaks between the methylene protons $\mathrm{H}_{2}-24(\delta 4.91, \delta 4.81 \mathrm{~d}, J=12.9 \mathrm{~Hz})$ and the carbon atoms C-7 ( $\delta 36.5)$ and $\mathrm{C}-14(\delta 55.0)$. The cyclopropyl group was assigned to the $C-3(\delta 17.9)$ and the $C-4(\delta 16.1)$ carbon atoms, based on a ${ }^{1} \mathrm{H},{ }^{1} \mathrm{H}$-COSY correlation between the methylene protons $\mathrm{H}_{2}-22$ ( $\delta-0.06 \mathrm{brt}, J=4.8 \mathrm{~Hz}, \delta 0.43 \mathrm{dd}, J=3.9$, $9.2 \mathrm{~Hz}$ ), and the methine proton $\mathrm{H}-3(\delta 0.55 \mathrm{~m})$, based on HMBC cross peaks between the protons $\mathrm{H}_{2}-22$ and the carbon atoms C-2 ( $\delta$ 19.0), C-5 ( $\delta$ 53.2) and C-21 ( $\delta 23.3)$. The entire assignment of all NMR data is given in Table 1.

The relative configuration was determined from proton coupling constants and NOE data (Table 1, Figure 4). NOESY cross peaks between $\mathrm{H}-3(\delta 0.55 \mathrm{~m})$, and $\mathrm{H}-22 \mathrm{a}(\delta 0.43 \mathrm{dd}, J=$ $3.9,9.2 \mathrm{~Hz}), \mathrm{H}_{3}-21$ ( $\delta 0.94 \mathrm{~s}$ ), and $\mathrm{H}_{3}-23$ ( $\delta 0.95 \mathrm{~s}$ ), as well as between $\mathrm{H}_{3}-23$ and $\mathrm{H}-24 \mathrm{a}(\delta 4.91 \mathrm{~d}, J=12.9 \mathrm{~Hz}), \mathrm{H}-24 \mathrm{~b}$ $(\delta 4.81 \mathrm{~d}, J=12.9 \mathrm{~Hz})$ and $\mathrm{H}_{3}-25(\delta 0.98 \mathrm{~s})$, and between $\mathrm{H}_{3}-25$ and $\mathrm{H}-19(\delta 5.24 \mathrm{~d}, J=4.4 \mathrm{~Hz}$ ), indicated that these protons share the same orientation on the molecular plane. The chemical shifts of the angular methyl groups $\mathrm{CH}_{3}-23(\delta 14.0)$ and $\mathrm{CH}_{3}-25$ ( $\delta 16.1$ ) suggested that all ring junctions are trans [58$60]$. This was supported by NOESY cross peaks between $\mathrm{H}-22 \mathrm{~b}$ $(\delta-0.06 \mathrm{brt}, J=4.8 \mathrm{~Hz})$ and $\mathrm{H}-5(\delta 0.92 \mathrm{~m})$, angular methines H-5 and H-9 ( $\delta 1.01 \mathrm{~s}$ ), H-9 and H-14 ( $\delta 1.40$ brt, $J=8.5 \mathrm{~Hz}$ ), and between $\mathrm{H}-14$ and $\mathrm{H}-18(\delta 2.15 \mathrm{~m})$, from which a shared $\alpha$-orientation can be inferred. Moreover, the cross peak between $\mathrm{H}-19(\delta 5.24 \mathrm{~d}, J=4.4 \mathrm{~Hz})$ and $\mathrm{H}_{3}-25(\delta 0.98 \mathrm{~s})$, and a coupling constant of $J=4.4 \mathrm{~Hz}$ between $\mathrm{H}-19$ and $\mathrm{H}-18$, further confirm the trans relationship between these protons. Hence,

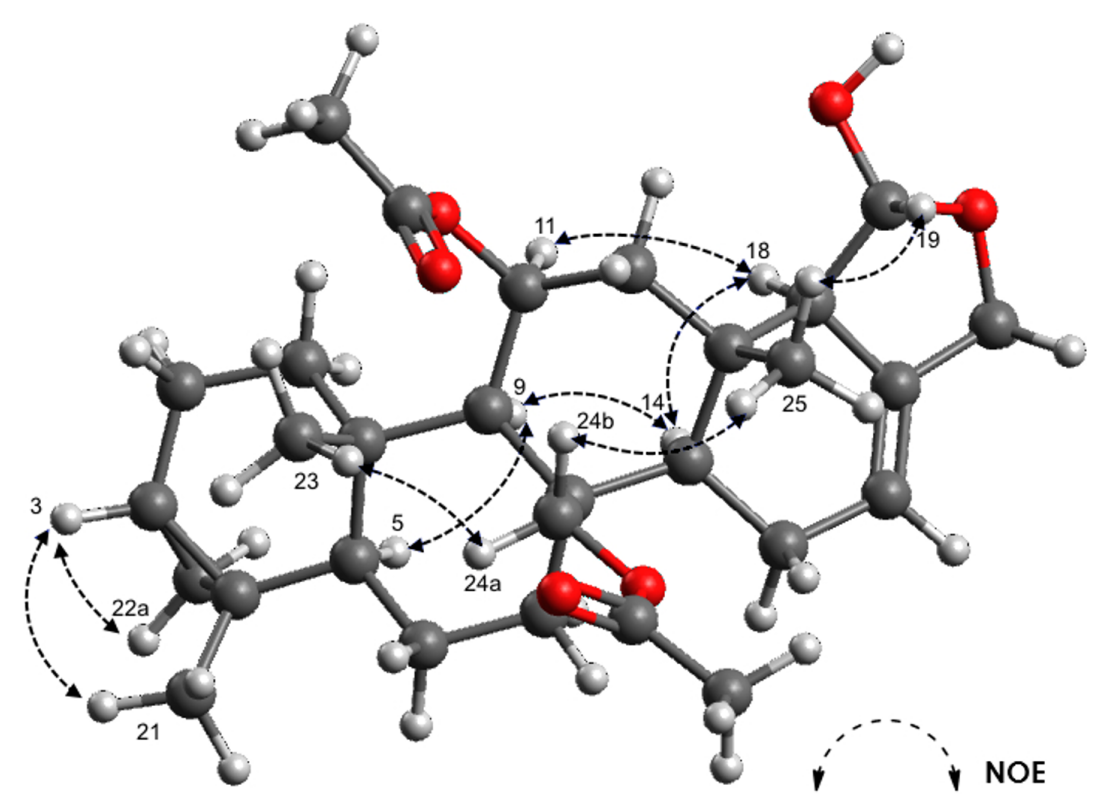

Figure 4: Proposed relative configuration of 12-deacetoxy-4-demethyl-11,24-diacetoxy-3,4-methylenedeoxoscalarin. Selected NOE correlations are indicated with arrows. The model was obtained using Avogadro, an open-source molecular builder and visualization tool, version 1.2.0. 
the structure and relative configuration of 12-deacetoxy-4demethyl-11,24-diacetoxy-3,4-methylenedeoxoscalarin was determined. It needs to be noted that the molecule was unstable over time, especially in ring $\mathrm{E}$, and a variety of degradation products formed by, inter alia, hydrolysis of the hemiacetal and loss of the acetoxy groups.

The new scalarane was also detected in Doriprismatica stellata egg ribbons and Spongia cf. agaricina (Figure 3). It was isolated from both samples (egg ribbons: $1 \mathrm{mg}, 0.1 \%$ wet weight; sponge: $0.7 \mathrm{mg}, 0.02 \%$ wet weight) and the identity was validated by comparison of the MS and NMR spectra.

\section{Antibacterial activity}

All ethyl acetate extracts from Doriprismatica stellata nudibranchs, egg ribbons and Spongia cf. agaricina showed antibacterial activity against the Gram-positive Arthrobacter crystallopoietes (DSM 20117) in a first screening approach. The pure compound 12-deacetoxy-4-demethyl-11,24-diacetoxy-3,4methylenedeoxoscalarin, isolated from all three extracts, was active against the Gram-positive Bacillus megaterium (DSM 32) (Supporting Information File 1).

\section{Discussion}

In this study, the new scalarane-type sesterterpene 12-deacetoxy-4-demethyl-11,24-diacetoxy-3,4-methylenedeoxoscalarin was isolated from Doriprismatica stellata nudibranchs (Gastropoda, Mollusca), their egg ribbons, and the associated sponge Spongia cf. agaricina (Demospongiae, Porifera), collected from Bunaken National Park (BNP, North Sulawesi, Indonesia). Nudibranchs and their egg ribbons revealed higher concentrations of the scalarane in comparison to the sponge, likely due to a continuous accumulation of this compound.

In general, scalarane sesterterpenes are bioactive metabolites, mainly isolated from marine sources, such as Dictyoceratida sponges and the nudibranchs that feed on them $[7,25,29,33,56]$ So far, only six scalaranes containing cyclopropane rings, constructed of C-4, C-19 and C-20, have been identified [61,62]. The new 12-deacetoxy-4-demethyl-11,24-diacetoxy3,4-methylenedeoxoscalarin shared high similarities with 12,24diacetoxydeoxoscalarin, a farnesoid X-activated receptor antagonist, isolated by Nam et al. from a Korean sponge of the genus Spongia [53]. However, differing from the previously reported scalaranes $[25,29,33,42,56,61,62]$, the new metabolite is functionalized at $\mathrm{C}-11$ instead of $\mathrm{C}-12$ and has a cyclopropane ring bridging $\mathrm{C}-3, \mathrm{C}-22$ and $\mathrm{C}-4$ of ring $\mathrm{A}$.

Scalarane sesterterpenes are considered as chemotaxonomic markers for the sponge families Thorectidae, Dysideidae and Spongiidae $[63,64]$. In Spongiidae, they have been isolated from the genera Coscinoderma [65], Hyattella [52,66], and Spongia [53,67-71]. Our results further support this chemotaxonomic classification, by the presence of 12-deacetoxy-4demethyl-11,24-diacetoxy-3,4-methylenedeoxoscalarin within Spongia cf. agaricina, (Spongiidae, Dictyoceratida).

Primordially, chromodorid nudibranchs feed upon a broad range of sponges, however, more derived genera like Glossodoris and Doriprismatica have taken to feeding upon a narrow range of sponges $[23,27,47]$. As the first chemical investigation of D. stellata nudibranchs, our results indicate that these sea slugs live and feed upon the dictyoceratid sponge Spongia cf. agaricina. This, among other investigations on Doriprismatica atromarginata $[38,41,44,45,50]$ and D. sedna [39], supports the idea of a stenophagous dietary relationship between nudibranchs of the genus Doriprismatica and scalarane-containing dictyoceratid sponges of the families Thorectidae and Spongiidae. This relationship is further reflected by their shared specialized metabolite 12-deacetoxy-4-demethyl-11,24-diacetoxy-3,4-methylenedeoxoscalarin, as proven in this study. Sesterterpenes are a rare terpene class, accounting for less than $2 \%$ of all known terpenoids, with only a few reports on their biosynthesis [72-76]. However, their frequent occurrence in marine organisms is striking and sponges are considered as the prime source of these terpenoids [25]. Yet determining the origin and in vitro production of these metabolites is anything but trivial. Sponges are known to host complex symbiont communities, with up to $30-60 \%$ as microbial biomass [13,77]. These highly species-specific communities are most probably vertically transmitted [78] and were shown to share and cover various core functions of sponge metabolism by functionally equivalent symbionts, analogous enzymes, or biosynthetic pathways $[16,79,80]$. Another Spongia species, S. officinalis, was shown to harbour bacteria with terpenoid cyclases/protein prenyltransferases responsible for a wide chemodiversity of terpenoid natural products $[14,81]$. Besides, the marine fungi Penicillium spp. and Aspergillus spp. are often associated with sponge hosts and were found to produce various terpenoids as well $[15,82,83]$. Hence, if sponges are not the origin of these metabolites, it is tempting to argue that the sesterterpene biosynthesis could be performed or mediated by their microbial symbionts. This further indicates a close association, interconnectedness, and probable co-evolution between microorganisms, sponges and nudibranchs [9]. D. stellata was not only found to sequester and accumulate 12-deacetoxy-4-demethyl11,24-diacetoxy-3,4-methylenedeoxoscalarin from Spongia cf. agaricina, but to pass it on to the egg ribbons as well. This, in addition to its bioactivity, might suggest a biological role, either as protection against predation, fouling, or in the reproductive cycle, as mentioned in previous studies on nudibranch egg ribbons [17,34-36]. The antibacterial activity of 12-deacetoxy- 
4-demethyl-11,24-diacetoxy-3,4-methylenedeoxoscalarin could point towards a potential protective role against bacterial biofilm formation. Unfortunately, the metabolite was unstable over time and it was not possible to conduct further assays. Future studies on scalarane sesterterpenes could reveal their full potential and true biological and ecological functions in complex, co-evolved communities.

\section{Experimental}

\section{General experimental procedures}

Optical rotations were measured with a Jasco DIP 140 polarimeter. UV and IR spectra were obtained using PerkinElmer Lambda 40 and Perkin-Elmer Spectrum BX instruments, respectively. All NMR spectra were acquired in base-filtered $\mathrm{CDCl}_{3}$ using Bruker Avance 300 DPX or Bruker Ascend 600 with prodigy cryoprobe spectrometers. Spectra were referenced to residual solvent signals with resonances at $\delta_{\mathrm{H} / \mathrm{C}} 7.26 /$ $77.00 \mathrm{ppm}\left(\mathrm{CDCl}_{3}\right)$. Mass spectra were recorded on a micrOTOF-Q mass spectrometer (Bruker) with ESI-source coupled with an HPLC Dionex Ultimate 3000 (Thermo Scientific) using an Agilent Zorbax Eclipse Plus $\mathrm{C}_{18}$ column $(2.1 \times 50 \mathrm{~mm}, 1.8 \mu \mathrm{m})$ at a temperature of $45^{\circ} \mathrm{C}$. MS data were acquired over a range from $100-3000 \mathrm{~m} / \mathrm{z}$ in positive mode. Auto MS/MS fragmentation was achieved with rising collision energy $(35-50 \mathrm{keV}$ over a gradient from $500-2000 \mathrm{~m} / \mathrm{z}$ ) with a frequency of $4 \mathrm{~Hz}$ for all ions over a threshold of 100. UHPLC started with $90 \% \mathrm{H}_{2} \mathrm{O}$ containing $0.1 \%$ acetic acid. The gradient began after $0.5 \mathrm{~min}$ to $100 \%$ acetonitrile $(0.1 \%$ acetic acid) in $4 \mathrm{~min} .2 \mu \mathrm{L}$ of a $1 \mathrm{mg} / \mathrm{mL}$ sample solution was injected to a flow of $0.8 \mathrm{~mL} / \mathrm{min}$. HRAPCIMS were recorded on LTQ Orbitrap XL mass spectrometer. HPLC was carried out on a Waters Breeze HPLC system equipped with a $1525 \mu$ dual pump, a 2998 DAD detector, and a Rheodyne 7725i injection system and with a Waters Alliance HPLC system equipped with a Waters 2695 separation module and a Waters 996 PDA detector. A Macherey-Nagel Nucleodur $\mathrm{C}_{18}$ Pyramid column $(250 \mathrm{~mm} \times 10 \mathrm{~mm} ; 5 \mu \mathrm{m})$ and a Phenomenex Kinetex $\mathrm{C}_{18}$ column $(250 \mathrm{~mm} \times 4.6 \mathrm{~mm}, 5 \mu \mathrm{m})$ were used for separation.

\section{Biological material}

Samples of Doriprismatica stellata sea slugs (Nudibranchia, Gastropoda, Mollusca), their egg ribbons and pieces of the sponge, on which they were found $(1.2 \mathrm{~g}, 0.7 \mathrm{~g}$, and $3.5 \mathrm{~g}$ wet weight, respectively) were collected via scuba diving in August 2015 during a field trip to Bunaken National Park (BNP, North Sulawesi, Indonesia, $1^{\circ} 37^{\prime} 51^{\prime \prime} \mathrm{N}, 124^{\circ} 45^{\prime} 05^{\prime \prime}$ E) at the coral reef drop off. Four additional D. stellata sea slugs $(2.5 \mathrm{~g}$ wet weight) were collected in October 2016 during another field trip to BNP. The nudibranchs and associated egg ribbons were identified as Doriprismatica stellata by H. Wägele and N. Undap at the Zoological Research Museum Alexander Koenig, Bonn,
Germany $[84,85]$. The sponge displayed a foliose habit with brownish-violett pigmentation and was identified as Spongia cf. agaricina using methods as described by Ackers et al. in 2007 [86], see also Erpenbeck et al. from 2020 [87] (Supporting Information File 1). Specimens were stored in ethanol (96\%) at $-20{ }^{\circ} \mathrm{C}$ until further extraction and processing in the laboratories at the University of Bonn. A part of the collected sea slug and substrate materials will be finally stored at the Sam Ratulangi University, Manado, Indonesia, in the Reference Collection under the numbers SRU2015/01 and SRU2016/02. A fraction of the sponge material is stored in the Bavarian State Collection for Paleontology and Geology under collection number SNSB-BSPG.GW41291.

\section{Extraction and isolation}

Six Doriprismatica stellata nudibranchs (3.7 $\mathrm{g}$ wet weight), their egg ribbons $(0.7 \mathrm{~g}$ wet weight $)$ and pieces of the associated sponge ( $3.5 \mathrm{~g}$ wet weight) were separately frozen, crushed and ultrasonicated for a total of 3 minutes ( $30 \mathrm{~s}$ intervals) on ice, while submerged in a minimum of first acetone (Ac) and consecutively methanol $(\mathrm{MeOH})$. The ethanolic storage solutions of D. stellata nudibranch, egg ribbon, and Spongia cf. agaricina samples were each combined with the respective $\mathrm{Ac} / \mathrm{MeOH}$ extracts of the samples and dried under vacuum to give the crude extracts. After liquid-liquid separation of the three crude extracts $(0.9 \mathrm{~g}, 0.3 \mathrm{~g}$, and $0.2 \mathrm{~g}$, respectively) between $50 \mathrm{~mL}$ water $\left(\mathrm{H}_{2} \mathrm{O}\right)$ and three times $50 \mathrm{~mL}$ ethyl acetate (EtOAc), EtOAc solubles (223 mg, $35 \mathrm{mg}$, and $81 \mathrm{mg}$ ) were separated by RP-HPLC. A Phenomenex Kinetex $\mathrm{C}_{18}$ column $(250 \mathrm{~mm} \times 4.6 \mathrm{~mm}, 5 \mu \mathrm{m})$, with a linear gradient elution from $70: 30\left(\mathrm{MeOH} / \mathrm{H}_{2} \mathrm{O}\right)$ to $100 \% \mathrm{MeOH}$ in $25 \mathrm{~min}$, and a flow of $1.5 \mathrm{~mL} / \mathrm{min}$ was used for separation. The isolated metabolite had a retention time around 13 minutes.

\section{2-Deacetoxy-4-demethyl-11,24-diacetoxy- 3,4-methylenedeoxoscalarin}

$\mathrm{C}_{29} \mathrm{H}_{42} \mathrm{O}_{6}$, white amorphous solid $(12.7 \mathrm{mg}) ;[\alpha]_{\mathrm{D}}{ }^{20}+40.5$ (c 0.6, $\mathrm{CHCl}_{3}$ ); IR (ATR) $v_{\max }: 3416,2922,2861,1732$, $1234 \mathrm{~cm}^{-1} ;{ }^{1} \mathrm{H}$ and ${ }^{13} \mathrm{C}$ NMR (Table 1); HRAPCIMS $(\mathrm{m} / \mathrm{z})$ : $[\mathrm{M}+\mathrm{H}]^{+}$calcd. for $\mathrm{C}_{29} \mathrm{H}_{43} \mathrm{O}_{6}, 487.3060$; found, 487.3054 .

\section{Supporting Information}

\section{Supporting Information File 1}

Spectroscopic data and other relevant information for 12-deacetoxy-4-demethyl-11,24-diacetoxy-3,4-methylened eoxoscalarin.

[https://www.beilstein-journals.org/bjoc/content/ supplementary/1860-5397-16-132-S1.pdf] 


\section{Acknowledgements}

We thank Dr. Henrik Harms for conducting the antimicrobial assays (grant No 9.818, DZIF, Innovative microbial resources for new anti-infectives). Furthermore, we thank Adrian Galitz for support in the laboratory and Rob W. M. van Soest, Nicole J. de Voogd, Steve C. de Cook, and Muhammad Abdul Wahab for discussions regarding the sponge identification. The organisms are listed in the collection event list of the Reference Collection of Sam Ratulangi University, Manado, Indonesia (SRU2015/01 SRU2016/02). Collection permits for all collected samples were provided by the Bunaken National Marine Park Authority for 2015 (SI.272/BTNB/PK/2015) and for 2016 (SI.399/BTNB/PK/2016).

\section{Funding}

We thank the German Federal Ministry of Education and Research (BMBF) for funding the project "INDOBIO Indonesian Opisthobranchs and associated microorganisms - From biodiversity to drug lead discovery" with grant numbers 16GW0117K (G.K. and T.S.) and 16GW0118 (H.W.).

\section{ORCID ${ }^{\circledR}$ iDs}

Dirk Erpenbeck - https://orcid.org/0000-0003-2716-1085 Till F. Schäberle - https://orcid.org/0000-0001-9947-8079 Gabriele M. König - https://orcid.org/0000-0003-0003-4916

\section{References}

1. Karuso, P. Chemical Ecology of the Nudibranchs. In Bioorganic Marine Chemistry; Scheuer, P. P. J., Ed.; Springer: Berlin, Heidelberg, 1987; pp 31-60. doi:10.1007/978-3-642-72726-9_2

2. Rogers, S. D.; Paul, V. J. Mar. Ecol.: Prog. Ser. 1991, 77, 221-232. doi:10.3354/meps077221

3. Pawlik, J. R. Chem. Rev. 1993, 93, 1911-1922. doi:10.1021/cr00021a012

4. Proksch, P. Toxicon 1994, 32, 639-655. doi:10.1016/0041-0101(94)90334-4

5. Avila, C.; Paul, V. J. Mar. Ecol.: Prog. Ser. 1997, 150, 171-180. doi:10.3354/meps 150171

6. Lindquist, N. J. Nat. Prod. 2002, 65, 681-684. doi:10.1021/np010339e

7. Gershenzon, J.; Dudareva, N. Nat. Chem. Biol. 2007, 3, 408-414. doi:10.1038/nchembio.2007.5

8. Zan, J.; Li, Z.; Tianero, M. D.; Davis, J.; Hill, R. T.; Donia, M. S. Science 2019, 364, eaaw6732. doi:10.1126/science.aaw6732

9. Guyot, M. Zoosystema 2000, 22, 419-431.

10. Taylor, M. W.; Radax, R.; Steger, D.; Wagner, M. Microbiol. Mol. Biol. Rev. 2007, 71, 295-347. doi:10.1128/mmbr.00040-06

11. Wilson, M. C.; Mori, T.; Rückert, C.; Uria, A. R.; Helf, M. J.; Takada, K.; Gernert, C.; Steffens, U. A. E.; Heycke, N.; Schmitt, S.; Rinke, C.; Helfrich, E. J. N.; Brachmann, A. O.; Gurgui, C.; Wakimoto, T.; Kracht, M.; Crüsemann, M.; Hentschel, U.; Abe, I.; Matsunaga, S.; Kalinowski, J.; Takeyama, H.; Piel, J. Nature 2014, 506, 58-62. doi:10.1038/nature12959
12. Kiran, G. S.; Sekar, S.; Ramasamy, P.; Thinesh, T.; Hassan, S.; Lipton, A. N.; Ninawe, A. S.; Selvin, J. Mar. Environ. Res. 2018, 140, 169-179. doi:10.1016/j.marenvres.2018.04.017

13. Thomas, T.; Moitinho-Silva, L.; Lurgi, M.; Björk, J. R.; Easson, C.; Astudillo-García, C.; Olson, J. B.; Erwin, P. M.; López-Legentil, S.; Luter, H.; Chaves-Fonnegra, A.; Costa, R.; Schupp, P. J.; Steindler, L.; Erpenbeck, D.; Gilbert, J.; Knight, R.; Ackermann, G.; Victor Lopez, J.; Taylor, M. W.; Thacker, R. W.; Montoya, J. M.; Hentschel, U.; Webster, N. S. Nat. Commun. 2016, 7, 11870. doi:10.1038/ncomms 11870

14. Karimi, E.; Ramos, M.; Gonçalves, J. M. S.; Xavier, J. R.; Reis, M. P.; Costa, R. Front. Microbiol. 2017, 8. doi:10.3389/fmicb.2017.02499

15. Petersen, L.-E.; Kellermann, M. Y.; Schupp, P. J. Secondary Metabolites of Marine Microbes: From Natural Products Chemistry to Chemical Ecology. In YOUMARES 9 - The Oceans: Our Research, Our Future: Proceedings of the 2018 conference for YOUng MArine RESearcher in Oldenburg, Germany; Jungblut, S.; Liebich, V.; Bode-Dalby, M., Eds.; Springer International Publishing: Cham, Switzerland, 2020; pp 159-180. doi:10.1007/978-3-030-20389-4_8

16. Freeman, C. J.; Easson, C. G.; Matterson, K. O.; Thacker, R. W.; Baker, D. M.; Paul, V. J. ISME J. 2020, 14, 1571-1583. doi:10.1038/s41396-020-0625-3

17. Pawlik, J. R.; Kernan, M. R.; Molinski, T. F.; Harper, M. K.; Faulkner, D. J. J. Exp. Mar. Biol. Ecol. 1988, 119, 99-109. doi:10.1016/0022-0981(88)90225-0

18. Faulkner, D.; Ghiselin, M. Mar. Ecol.: Prog. Ser. 1983, 13, 295-301. doi:10.3354/meps013295

19. Faulkner, D. J. Nat. Prod. Rep. 1984, 1, 551-598. doi:10.1039/np9840100551

20. Faulkner, D. J. Nat. Prod. Rep. 1988, 5, 613-663. doi:10.1039/np9880500613

21. Faulkner, D. J. Nat. Prod. Rep. 1992, 9, 323-364. doi:10.1039/np9920900323

22. Avila, C. Natural Products of Opisthobranch Molluscs: A Biological Review. In Oceanography and Marine Biology - an Annual Review; Ansell, A. D.; Gibson, R. N.; Barnes, M., Eds.; UCL Press Ltd.: London, 1995; Vol. 33, pp 487-559.

23. Cimino, G.; Ghiselin, M. T. Chemoecology 1999, 9, 187-207. doi:10.1007/s000490050052

24. Wägele, H.; Klussmann-Kolb, A. Front. Zool. 2005, 2, 3. doi:10.1186/1742-9994-2-3

25. Gross, H.; König, G. M. Phytochem. Rev. 2006, 5, 115-141. doi:10.1007/s11101-005-5464-3

26. Wahidullah, S.; Guo, Y.-W.; Fakhr, I. M. I.; Mollo, E. Chemical Diversity in Opisthobranch Molluscs from Scarcely Investigated Indo-Pacific Areas. In Molluscs: From Chemo-ecological Study to Biotechnological Application; Cimino, G.; Gavagnin, M., Eds.; Progress in Molecular and Subcellular Biology; Springer: Berlin, Heidelberg, 2006; pp 175-198. doi:10.1007/978-3-540-30880-5_8

27. Rudman, W. B.; Bergquist, P. R. Molluscan Res. 2007, 27, 60-88.

28. Kamel, H. N.; Kim, Y. B.; Rimoldi, J. M.; Fronczek, F. R.; Ferreira, D.; Slattery, M. J. Nat. Prod. 2009, 72, 1492-1496. doi:10.1021/np900326a

29. Gonzalez, M. A. Curr. Bioact. Compd. 2010, 6, 178-206. doi:10.2174/157340710793237362

30. Dean, L. J.; Prinsep, M. R. Nat. Prod. Rep. 2017, 34, 1359-1390. doi:10.1039/c7np00041c

31. Fisch, K. M.; Hertzer, C.; Böhringer, N.; Wuisan, Z. G.; Schillo, D.; Bara, R.; Kaligis, F.; Wägele, H.; König, G. M.; Schäberle, T. F. Mar. Drugs 2017, 15, 384. doi:10.3390/md15120384 
32. Avila, C.; Núñez-Pons, L.; Moles, J. From the Tropics to the Poles: Chemical Defense Strategies in Sea Slugs (Mollusca: Heterobranchia). In Chemical Ecology: The Ecological Impacts of Marine Natural Products; Puglisi, M. P.; Becerro, M. A., Eds.; CRC Press: Boca Raton, FL, USA, 2019; pp 71-164. doi:10.1201/9780429453465-3

33. Avila, C. Mar. Drugs 2020, 18, 162. doi:10.3390/md18030162

34. Salvitti, L. R.; Wood, S. A.; Winsor, L.; Cary, S. C. Mar. Drugs 2015, 13, 756-769. doi:10.3390/md13020756

35. Dumdei, E. J.; Kubanek, J.; Coleman, J. E.; Pika, J.; Andersen, R. J.; Steiner, J. R.; Clardy, J. Can. J. Chem. 1997, 75, 773-789. doi:10.1139/v97-094

36. Avila, C.; Cimino, G.; Crispino, A.; Spinella, A. Experientia 1991, 47, 306-310. doi:10.1007/bf01958169

37. Fontana, A.; Mollo, E.; Ricciardi, D.; Fakhr, I.; Cimino, G. J. Nat. Prod. 1997, 60, 444-448. doi:10.1021/np960690d

38. Fontana, A.; Cavaliere, P.; Ungur, N.; D'Souza, L.; Parameswaram, P. S.; Cimino, G. J. Nat. Prod. 1999, 62, 1367-1370. doi:10.1021/np9900932

39. Fontana, A.; Mollo, E.; Ortea, J.; Gavagnin, M.; Cimino, G. J. Nat. Prod. 2000, 63, 527-530. doi:10.1021/np990506z

40. Gavagnin, M.; Mollo, E.; Docimo, T.; Guo, Y.-W.; Cimino, G. J. Nat. Prod. 2004, 67, 2104-2107. doi:10.1021/np040087s

41. Somerville, M. J.; Mollo, E.; Cimino, G.; Rungprom, W.; Garson, M. J. J. Nat. Prod. 2006, 69, 1086-1088. doi:10.1021/np060002i

42. Manzo, E.; Gavagnin, M.; Somerville, M. J.; Mao, S.-C.; Ciavatta, M. L.; Mollo, E.; Schupp, P. J.; Garson, M. J.; Guo, Y.-W.; Cimino, G. J. Chem. Ecol. 2007, 33, 2325-2336. doi:10.1007/s10886-007-9387-x

43. Mudianta, I. W.; White, A. M.; Suciati; Katavic, P. L.; Krishnaraj, R. R.; Winters, A. E.; Mollo, E.; Cheney, K. L.; Garson, M. J. Pure Appl. Chem. 2014, 86, 995-1002. doi:10.1515/pac-2013-1111

44. Yong, K. W. L.; Mudianta, I. W.; Cheney, K. L.; Mollo, E.; Blanchfield, J. T.; Garson, M. J. J. Nat. Prod. 2015, 78, 421-430. doi:10.1021/np500797b

45. Li, X.-L.; Li, S.-W.; Yao, L.-G.; Mollo, E.; Gavagnin, M.; Guo, Y.-W. Magn. Reson. Chem. 2020, in press. doi:10.1002/mrc.4949

46. Turner, L. M.; Wilson, N. G. Zool. Scr. 2008, 37, 23-42. doi:10.1111/j.1463-6409.2007.00310.x

47. Johnson, R. F.; Gosliner, T. M. PLoS One 2012, 7, e33479. doi:10.1371/journal.pone.0033479

48. Matsuda, S. B.; Gosliner, T. M. Cladistics 2018, 34, 41-56. doi:10.1111/cla.12194

49. Matsuda, S. B.; Gosliner, T. M. Zootaxa 2018, 4444, 501-529. doi:10.11646/zootaxa.4444.5.1

50. Dilip de Silva, E.; Scheuer, P. Heterocycles 1982, 17, 167. doi:10.3987/s-1982-01-0167

51. Betancur-Galvis, L.; Zuluaga, C.; Arnó, M.; González, M. A.; Zaragozá, R. J. J. Nat. Prod. 2002, 65, 189-192. doi:10.1021/np010206t

52. Somerville, M. J.; Hooper, J. N. A.; Garson, M. J. J. Nat. Prod. 2006, 69, 1587-1590. doi:10.1021/np060244i

53. Nam, S.-J.; Ko, H.; Shin, M.; Ham, J.; Chin, J.; Kim, Y.; Kim, H.; Shin, K.; Choi, H.; Kang, H. Bioorg. Med. Chem. Lett. 2006, 16, 5398-5402. doi:10.1016/j.bmcl.2006.07.079

54. Evidente, A.; Kornienko, A.; Lefranc, F.; Cimmino, A.; Dasari, R.; Evidente, M.; Mathieu, V.; Kiss, R. Curr. Med. Chem. 2015, 22 , 3502-3522. doi:10.2174/0929867322666150821101047

55. Wu, S.-Y.; Sung, P.-J.; Chang, Y.-L.; Pan, S.-L.; Teng, C.-M. BioMed Res. Int. 2015, 738241. doi:10.1155/2015/738241

56. Máximo, P.; Lourenço, A. Curr. Org. Chem. 2018, 22, 2381-2393. doi:10.2174/1385272822666181029101212
57. Kolesnikova, S. A.; Lyakhova, E. G.; Diep, C. N.; Tu, V. A.; Huong, P. T.; Kalinovskii, A. I.; Dmitrenok, P. S.; Nam, N. H.; Stonik, V. A. Chem. Nat. Compd. 2017, 53, 194-195. doi:10.1007/s10600-017-1948-9

58. Crews, P.; Naylor, S. Sesterterpenes: An Emerging Group of Metabolites from Marine and Terrestrial Organisms. Fortschritte der Chemie organischer Naturstoffe /Progress in the Chemistry of Organic Natural Products; Springer: Vienna, 1985; pp 203-269. doi:10.1007/978-3-7091-8815-6_3

59. Crews, P.; Bescansa, P. J. Nat. Prod. 1986, 49, 1041-1052. doi:10.1021/np50048a012

60. Roy, M. C.; Tanaka, J.; de Voogd, N.; Higa, T. J. Nat. Prod. 2002, 65, 1838-1842. doi:10.1021/np020311i

61. Wang, Q.; Sun, Y.; Yang, L.; Luo, X.; de Voogd, N. J.; Tang, X.; Li, P.; Li, G. J. Nat. Prod. 2020, 83, 516-523. doi:10.1021/acs.jnatprod.9b01202

62. Jiménez, J. I.; Yoshida, W. Y.; Scheuer, P. J.; Kelly, M. J. Nat. Prod. 2000, 63, 1388-1392. doi:10.1021/np0000771

63. Jaspars, M.; Jackson, E.; Lobkovsky, E.; Clardy, J.; Diaz, M. C.; Crews, P. J. Nat. Prod. 1997, 60, 556-561. doi:10.1021/np960147x

64. Erpenbeck, D.; van Soest, R. W. M. Mar. Biotechnol. 2007, 9, 2. doi:10.1007/s10126-005-6109-7

65. Kimura, J.; Hyosu, M. Chem. Lett. 1999, 28, 61-62. doi:10.1246/cl.1999.61

66. Hernández-Guerrero, C. J.; Zubía, E.; Ortega, M. J.; Carballo, J. L. Tetrahedron 2006, 62, 5392-5400. doi:10.1016/j.tet.2006.03.075

67. Terem, B.; Scheuer, P. J. Tetrahedron 1986, 42, 4409-4412. doi:10.1016/s0040-4020(01)87279-3

68. Davis, R.; Capon, R. J. Aust. J. Chem. 1993, 46, 1295-1299. doi:10.1071/ch9931295

69. Tsukamoto, S.; Miura, S.; van Soest, R. W. M.; Ohta, T. J. Nat. Prod. 2003, 66, 438-440. doi:10.1021/np020497।

70. Phan, C.-S.; Kamada, T.; Hamada, T.; Vairappan, C. S. Rec. Nat. Prod. 2018, 12, 643-647. doi:10.25135/rnp.69.18.01.209

71. Yang, I.; Lee, J.; Lee, J.; Hahn, D.; Chin, J.; Won, D. H.; Ko, J.; Choi, H.; Hong, A.; Nam, S.-J.; Kang, H. Molecules 2018, 23, 3187. doi:10.3390/molecules23123187

72. Chiba, R.; Minami, A.; Gomi, K.; Oikawa, H. Org. Lett. 2013, 15, 594-597. doi:10.1021/ol303408a

73. Ye, Y.; Minami, A.; Mandi, A.; Liu, C.; Taniguchi, T.; Kuzuyama, T.; Monde, K.; Gomi, K.; Oikawa, H. J. Am. Chem. Soc. 2015, 137, 11846-11853. doi:10.1021/jacs.5b08319

74. Matsuda, Y.; Mitsuhashi, T.; Quan, Z.; Abe, I. Org. Lett. 2015, 17, 4644-4647. doi:10.1021/acs.orglett.5b02404

75. Chai, H.; Yin, R.; Liu, Y.; Meng, H.; Zhou, X.; Zhou, G.; Bi, X.; Yang, X.; Zhu, T.; Zhu, W.; Deng, Z.; Hong, K. Sci. Rep. 2016, 6, 27181. doi:10.1038/srep27181

76. Mitsuhashi, T.; Rinkel, J.; Okada, M.; Abe, I.; Dickschat, J. S. Chem. - Eur. J. 2017, 23, 10053-10057. doi:10.1002/chem.201702766

77. Mehbub, M. F.; Lei, J.; Franco, C.; Zhang, W. Mar. Drugs 2014, 12, 4539-4577. doi:10.3390/md12084539

78. Schmitt, S.; Tsai, P.; Bell, J.; Fromont, J.; Ilan, M.; Lindquist, N.; Perez, T.; Rodrigo, A.; Schupp, P. J.; Vacelet, J.; Webster, N.; Hentschel, U.; Taylor, M. W. ISME J. 2012, 6, 564-576. doi:10.1038/ismej.2011.116

79. Thomas, T. R. A.; Kavlekar, D. P.; LokaBharathi, P. A. Mar. Drugs 2010, 8, 1417-1468. doi:10.3390/md8041417

80. Fan, L.; Reynolds, D.; Liu, M.; Stark, M.; Kjelleberg, S.; Webster, N. S.; Thomas, T. Proc. Natl. Acad. Sci. U. S. A. 2012, 109, E1878-E1887. doi:10.1073/pnas.1203287109 
81. Christianson, D. W. Chem. Rev. 2017, 117, 11570-11648. doi:10.1021/acs.chemrev.7b00287

82. Wiese, J.; Ohlendorf, B.; Blümel, M.; Schmaljohann, R.; Imhoff, J. F. Mar. Drugs 2011, 9, 561-585. doi:10.3390/md9040561

83. Rateb, M. E.; Ebel, R. Nat. Prod. Rep. 2011, 28, 290-344. doi:10.1039/c0np00061b

84. Kaligis, F.; Eisenbarth, J.-H.; Schillo, D.; Dialao, J.; Schäberle, T. F.; Böhringer, N.; Bara, R.; Reumschüssel, S.; König, G. M.; Wägele, H. Mar. Biodivers. Rec. 2018, 11, 2. doi:10.1186/s41200-018-0136-3

85. Eisenbarth, J.-H.; Undap, N.; Papu, A.; Schillo, D.; Dialao, J.; Reumschüssel, S.; Kaligis, F.; Bara, R.; Schäberle, T. F.; König, G. M.; Yonow, N.; Wägele, H. Diversity 2018, 10, 127. doi:10.3390/d10040127

86. Ackers, R. G.; Moss, D.; Picton, B. E.; Bt, B.; Stone, S. M. K.; Morrow, C. C. Mar. Conserv. Soc. 2007, 165.

87. Erpenbeck, D.; Galitz, A.; Ekins, M.; Cook, S. de C.; van Soest, R. W. M.; Hooper, J. N. A.; Wörheide, G. J. Zool. Syst. Evol. Res. 2020, 58, 27-40. doi:10.1111/jzs.12351

\section{License and Terms}

This is an Open Access article under the terms of the Creative Commons Attribution License (http://creativecommons.org/licenses/by/4.0). Please note that the reuse, redistribution and reproduction in particular requires that the authors and source are credited.

The license is subject to the Beilstein Journal of Organic Chemistry terms and conditions: (https://www.beilstein-journals.org/bjoc)

The definitive version of this article is the electronic one which can be found at: $\underline{\text { doi:10.3762/bjoc. } 16.132}$ 